NBER WORKING PAPER SERIES

\title{
ESTIMATING LIFE-CYCLE PARAMETERS FROM CONSUMPTION BEHAVIOR AT RETIREMENT
}

\author{
John Laitner \\ Dan Silverman \\ Working Paper 11163 \\ http://www.nber.org/papers/w11163 \\ NATIONAL BUREAU OF ECONOMIC RESEARCH \\ 1050 Massachusetts Avenue \\ Cambridge, MA 02138 \\ March 2005
}

Osamu Aruga and Lina Walker provided excellent research assistance with the CEX and HRS data sets, respectively. We are grateful to John Bound, Miles Kimball, Jeff Liebman, Richard Rogerson, Matthew Shapiro and participants in seminars at Arizona State University, the University of Minnesota, the University of Michigan, Osaka University and Tokyo University for their helpful comments. This work was supported by a grant from the Social Security Administration through the Michigan Retirement Research Center (Grant \# 10-P-98358-5). The opinions and conclusions are solely those of the authors and should not be considered as representing the opinions or policy of the Social Security Administration or any agency of the Federal Government. The views expressed herein are those of the author(s) and do not necessarily reflect the views of the National Bureau of Economic Research.

(C) 2005 by John Laitner and Dan Silverman. All rights reserved. Short sections of text, not to exceed two paragraphs, may be quoted without explicit permission provided that full credit, including $(\odot$ notice, is given to the source. 
Estimating Life-Cycle Parameters from Consumption Behavior at Retirement John Laitner and Dan Silverman

NBER Working Paper No. 11163

March 2005

JEL No. E21, D11, D12

\begin{abstract}
Using pseudo-panel data, we estimate the structural parameters of a life--cycle consumption model with discrete labor supply choice. A focus of our analysis is the abrupt drop in consumption upon retirement for a typical household. The literature sometimes refers to the drop, which in the U.S. Consumer Expenditure Survey we estimate to be approximately 16\%, as the "retirement-consumption puzzle." Although a downward step in consumption at retirement contradicts predictions from life--cycle models with additively separable consumption and leisure, or with continuous work-hour options, a consumption jump is consistent with a setup having nonseparable preferences over consumption and leisure and requiring discrete work choices. This paper specifies a life--cycle model with these latter two elements, and it uses the empirical magnitude of the drop in consumption at retirement to provide an advantageous method of identifying structural parameters --- most importantly, the intertemporal elasticity of substitution.
\end{abstract}

John Laitner

University of Michigan

611 Tappan Avenue, Lorch 238

Ann Arbor, MI 48109

jlaitner@umich.edu

Dan Silverman

University of Michigan

611 Tappan Avenue, Lorch 238

Ann Arbor, MI 48109

and NBER

dansilv@umich.edu 


\section{Estimating Life-Cycle Parameters from \\ Consumption Behavior at Retirement}

\section{Introduction}

The life-cycle saving model is a cornerstone of modern economic policy analysis. Researchers use the framework to study, among other topics, economic growth, business cycles, social insurance, and trade and tax policies (e.g., Diamond [1965], Auerbach and Kotlikoff [1987], Lucas [1990, 2003], Hubbard et al. [1995], Altig et al. [2001], and many others). In a number of applications, both the model's ability to match data and the answer it gives to economic questions depend critically on values of its parameters, especially the intertemporal elasticity of substitution for consumption. For example, see Woodford [2003, ch.4] on macroeconomic implications, Weil [1989] on the risk free rate puzzle, Lucas [2003] on the welfare costs of business cycles, and Jones et al. [2003] on the relationship between volatility and growth. The importance of the model's parameters naturally generates interest in credible and precise estimates of their magnitudes (e.g., Hall [1988], Campbell and Mankiw [1989], and Attanasio and Weber [1993]). Controversy about parameter values nevertheless persists, in part due to data limitations. We believe, however, that the recent literature documenting the drop in average household consumption expenditure at retirement - the "retirement-consumption puzzle" — suggests a new avenue for progress. With the goal of enhancing the life-cycle model's usefulness for current and future policy research, this paper reconciles the model with empirical evidence on the change in households' expenditure at retirement and then uses the magnitude of that change as a novel and, we argue, advantageous source of identification in estimating parameters.

A number of recent papers describe a substantial drop in household expenditures at retirement. ${ }^{1}$ Some authors view the sudden change in expenditures as a puzzle. Indeed,

\footnotetext{
${ }^{1}$ E.g., Banks et al. [1998], Bernheim et al. [2001], Hurd and Rohwedder [2003], Haider
} 
a central prediction of the life-cycle model is that agents should smooth marginal utility across ages, and, in the simplest formulations of model, this prediction maps into an optimal life-cycle path of consumption that is itself smooth. When, for example, retirement is anticipated, and when utility is an additively separable function of consumption and leisure, consumption should change continuously with age.

However, preferences over consumption and leisure may not take an additively separable form. ${ }^{2}$ Furthermore, a number of economists argue that opportunities for market-work hours are not continuous. We show formally below that a tractable life-cycle specification with intratemporal utility that is nonseparable in consumption and leisure, with work options that are discrete, and with a retirement age that emerges from household choice, predicts a discontinuous consumption change at retirement.

We then show that if one is willing to treat the change in household consumption at retirement as a consequence of purposeful behavior, the magnitude of the change provides useful information for estimating life-cycle model parameters. Consider the intertemporal elasticity of substitution (IES). Suppose that consumption and leisure are complements (i.e., that we have intratemporal nonseparability) and that a household anticipates a discrete increase in leisure upon retiring. In that case, the household will want to change its consumption abruptly at retirement; moreover, the direction and magnitude of the desired change will depend on the household's taste for smoothing utility over time, that is, on its IES for consumption/leisure services. In particular, if a household's taste for intertemporal smoothing is high, it may choose to decrease its consumption at retirement so that lost utility from consumption offsets gains from additional leisure. If, on the other hand, it has

and Stephens [2004], and Aguiar and Hurst [2004]. The decline estimated in these papers ranges from $7 \%$ to $35 \%$.

${ }^{2}$ Indeed Attanasio and Weber [1993] and Meghir and Weber [1996] argue that allowing for nonseparability is crucial for fitting the data. 
a lower desire for intertemporal smoothing, a household might increase its consumption at retirement — to take advantage of the complementarity of consumption and leisure. The size, and sign, of the consumption change registered in the data can thus help us to estimate households' IES.

By offering an alternative method for identifying life-cycle parameters, especially the IES, this paper contributes to a literature that has formed two basic strands. The first calibrates the life-cycle model from (macro) data and various existing studies (e.g., Auerbach and Kotlikoff [1987], Cooley and Prescott [1995], and Altig et al. [2001]). This strand tends to favor a moderate IES for consumption, usually between 0.2 and 1.0. The second strand of the literature typically identifies the IES for consumption with the coefficient on the, properly instrumented, rate of return on assets in a consumption Euler equation. This strand includes analyses of macro data, which sometimes estimate an IES very near zero (e.g., Hall [1988], Campbell and Mankiw [1989]), and analyses of micro data, which typically estimate an IES between 0.5 and 0.8 (e.g., Attanasio and Weber [1993] and Banks et al. [1998]). Our approach can contribute evidence on the robustness of IES estimates to variation in method of estimation and decision domain. ${ }^{3}$

Furthermore, our method has the advantage that it estimates the IES from changes

3 Other papers have provided alternative methods for estimating and IES parameter. For example, Barsky et al. [1997] use the responses to hypothetical questions to estimate the IES. Estimating fully specified structural models, Rust and Phelan [1997] identify an IES from the labor supply and Social Security application decisions of older males; and Keane and Wolpin [2001] identify an IES for services from the decisions of young men concerning schooling, work and saving. Using aggregate data, Basu and Kimball [2003] implement a model with nonseparable consumption and leisure and with income and substitution effects on labor supply that cancel. Their method indicates an IES of 0.5 since the $1980 \mathrm{~s}$, but it is unstable for earlier data from the postwar period. 
associated with a highly predictable and consequential life event, namely, retirement. The standard strategy of instrumenting for asset returns in period $t+1$ using economic variables known in period $t$ suffers from two limitations. First, the relevant variation (anticipated changes in real rates of return) is modest in size, in practice perfectly correlated across individuals in a cross section and, therefore, seems unlikely to produce changes in behavior that are large enough to be precisely estimated from available data. Second, changes in asset returns are notoriously difficult to predict. As a result, problems of weak instruments arise. ${ }^{4}$ This paper's identification strategy, in contrast, depends on a phenomenon that is economically substantial, mostly anticipated, and independently repeated within cross sections of data. In addition, our method has the advantage that it does not rely on unmodeled sources of variation. Interpreting rate-of-return estimates may require a specification with household decision making under uncertainty, household prediction of the distribution for future shocks, and even transactions costs - all elements beyond the scope of many policy-simulation models. Our procedure, on the other hand, straightforwardly employs a model designed for policy experiments.

Our approach relies on interpreting the change in expenditure at retirement as intentional. Haider and Stephens [2004] test an alternative idea that consumption declines on average at retirement because retirement is often unexpected. Using subjective predictions about retirement age as an instrument for anticipated retirement, they find that the expenditure decline remains statistically and economically significant (though one-third smaller than with non-IV estimates). In a related study, Hurd and Rohwedder [2003] use novel survey questions about expectations and show that households anticipate that their consumption will dip about $20 \%$ at retirement. Similarly, Laitner [2001] points out that

4 See Yogo [2004] for a thorough discussion. An advantage, nevertheless, of using anticipated changes in asset returns to estimate the IES is that the validity of the estimate does not depend on a particular functional form for the utility function. 
financial advisors have long said that retirees should plan for less consumption than working people: he quotes a TIAA-CREF brochure stating that "you'll need 60 to 90 percent of current income in retirement, adjusted for inflation, to maintain the lifestyle you now lead," and he cites a popular press article writing that "many financial planners say it will take 70 to 80 percent of your current income to maintain your standard of living when you retire." These sources suggest that households anticipate a drop in consumption at retirement and, therefore, that this change is intentional.

We employ two data sets. We use pseudo-panel data from the U.S. Consumer Expenditure Survey 1984-2001 to estimate a consumption-Euler equation. The estimated coefficients are composites of underlying parameters from a life-cycle model with nonseparable consumption and leisure. As in previous studies, we find a substantial average drop in household expenditure at retirement. Combining the consumption coefficients, a life-cycle model, and lifetime earnings profiles from the Health and Retirement Study (HRS) panel data, we use an equation measuring the model's predicted optimal retirement age against HRS data on retirement to extract estimates of structural parameters. We estimate, quite precisely, intertemporal elasticity parameter values that are on the higher end of those found and used in the literature: our IES for services is approximately 0.67 , and we estimate an IES for consumption of 0.87 . We then assess the model's "out-of-sample" fit by comparing its prediction of average household wealth at retirement with HRS data on middle class net worth (data which did not inform the estimation). Despite the inclusion of a drop in consumption at retirement, our model matches the wealth data remarkably well.

The organization of this paper is as follows. Section 2 discusses several of our key assumptions. Section 3 presents our model and estimation strategy. Sections $4-5$ discuss our data and present our estimates. Section 6 compares simulations from our model with HRS data on household net worth. Section 7 concludes. 


\section{Assumptions}

In this paper's model, every household chooses its saving and labor supply to maximize its utility subject to a lifetime budget constraint. Our analysis assumes that (1) the work day is indivisible, (2) private-pension formulas do not affect workers' retirement age, (3) household preference orderings may be intratemporally nonseparable with respect consumption and leisure, and (4) perfect markets exist for annuities, health and disability insurance. Our rationale for assumptions (1)-(3) is as follows.

Assumption 1: The work day is indivisible.

Households in our analysis must either work full time or retire. While in practice employers do offer part-time jobs, the rate of pay is, on average, substantially lower than that for full-time work. ${ }^{5}$ As Rust and Phelan [1997, p.786] write,

The finding that most workers make discontinuous transitions from fulltime work to not working, and the finding that the majority of the relatively small number of 'gradual retirees' reduce their annual hours of work by taking on a sequence of lower wage partial retirement 'bridge jobs' rather than gradually reducing hours of work at their full-time pre-retirement 'career job' suggests the existence of explicit or implicit constraints on the individual's choice of hours of work.

An indivisibility assumption is also consistent with the fact that U.S. data show little trend in male work hours or participation rates after 1940, except for a trend toward earlier retirement 1940-80 (e.g., Pencavel [1986], Blundell and MaCurdy [1999], and Burkhauser

${ }^{5}$ Reasons for the wage penalty for part-time work include daily fixed costs of startup and shutdown, scheduling and coordination problems, employer concern for timely return on training investments, and the fixed-cost nature of some employee benefits (e.g., Hurd [1996]). 
et al. [1999]).

Assumption 2: Pension formulas do not affect retirement ages.

Although some analyses stress the importance of workers' private pension plans as determinants of retirement behavior (e.g., Gustman and Steinmeier [1986], Stock and Wise [1990]), we assume that a worker chooses an employer whose pension plan matches his requirements; thus, in this paper, private pensions form a part of private wealth accumulation and do not require separate attention. Arguments in favor of explicitly modeling the distinct features of private pensions seem most applicable to defined benefit plans; however, in practice defined contribution plans have become more important. Even in the past, many of the features of defined benefit plans originated at union initiative or during collective bargaining, and thus presumably reflected worker preferences.

Assumption 3: Utility is intratemporally nonseparable in consumption and leisure.

Although, for the sake of simplicity, this paper's analysis assumes household preference orderings are intertemporally separable, it makes consumption and leisure intratemporally nonseparable. Since intratemporal nonseparability is central to this paper's focus, we examine its implications in detail.

To see the restrictions imposed by intratemporal separability, consider a specific example. A single-person household lives from $t=0$ to $t=T$, choosing to retire at $t=R$. The household's time endowment at each age is 1; when the household works, its leisure falls to $\bar{\ell} \in(0,1)$. According to assumption (1), indivisibilities force $\bar{\ell}$ to be a fixed parameter. The wage is $w$; the interest rate is $r$. A household's consumption $c_{t}$ yields utility flow $u\left(c_{t}\right)$; its leisure $\ell_{t}$ yields utility flow $v\left(\ell_{t}\right)$; and, its assets (net worth) are $a_{t}$. The household's behavior solves

$$
\max _{R, c_{t}} \int_{0}^{T}\left[u\left(c_{t}\right)+v\left(\ell_{t}\right)\right] d t
$$




$$
\begin{gathered}
\text { subject to: } \ell_{t}= \begin{cases}\bar{\ell}, & \text { for } t<R \\
1, & \text { for } t \geq R\end{cases} \\
\dot{a}_{t}=r \cdot a_{t}+\left(1-\ell_{t}\right) \cdot w-c_{t}, \\
a_{0}=0=a_{T} .
\end{gathered}
$$

As utility depends on the sum $u(c)+v(\ell)$, this is the separable case.

Provided $u($.$) is concave, specification (1) predicts that, even with a discrete increase$ in leisure at retirement, there should be no abrupt change in consumption at that time. To see this note that, along an optimal consumption path, the additional utility at date $s$ from one extra dollar's consumption, $u^{\prime}\left(c_{s}\right)$, must equal the additional utility from the dollar if it were saved until later date $t$, by which time it will have grown to an amount $e^{r \cdot(t-s)}$. That is,

$$
u^{\prime}\left(c_{s}\right)=e^{r \cdot(t-s)} \cdot u^{\prime}\left(c_{t}\right)
$$

the so-called "Euler equation" for consumption. Letting $c_{t-}$ be consumption the instant before $t$, and $c_{t+}$ the instant after, condition (2) yields

$$
u^{\prime}\left(c_{t-}\right)=u^{\prime}\left(c_{t+}\right)
$$

With $u^{\prime}($.$) continuous, equation (3) is inconsistent with a jump in consumption at any age,$ including at the age of retirement.

While intratemporal additivity is the most common specification for utility in the life-cycle literature, a number of authors instead assume nonseparable preferences. A 
well-known example is Auerbach and Kotlikoff [1987]. ${ }^{6}$ We can easily modify example (1) to accommodate their alternative. Let a household have a constant returns to scale "neoclassical" production function $f: R^{2} \mapsto R^{1}$ that combines current consumption and leisure to generate a flow of services, the latter yielding a flow of utility, say, $u(f)$. The first line of (1) changes to

$$
\max _{R, c_{t}} \int_{0}^{T} u\left(f\left(c_{t}, \ell_{t}\right)\right) d t
$$

though constraints can remain the same. Because a bivariate constant-returns-to-scale neoclassical production function has $f_{12}()>$.0 , inputs are complementary in the sense that more leisure (consumption) raises the marginal product of consumption (leisure). If $u($.$) were linear, this complementarity would make the household want to increase its$ consumption at (and after) retirement to take advantage of the increased marginal utility of consumption that derives from higher leisure. If, on the other hand, $u($.$) is sufficiently$ concave, the household would strongly desire a smooth flow of services at different ages; hence, it would plan more consumption prior to $t=R$ to counterbalance its abundant service flow from leisure later. In the end, with nonseparability, rational behavior may lead to an age profile of consumption which discontinuously changes in either direction at retirement.

A specific parameterization with nonseparable consumption and leisure makes clear the connection between the change in consumption at retirement and the structural parameters of the life--cycle model, and it will form the framework for our empirical analysis later. Let the intratemporal household production function $f($.$) be Cobb-Douglas:$

$$
f(c, \ell)=[c]^{\alpha} \cdot[\ell]^{1-\alpha}, \quad \alpha \in(0,1) .
$$

\footnotetext{
${ }^{6}$ See also King et al. [1988], Hurd and Rohwedder [2003], Cooley and Prescott [1995].
} 
Let $u($.$) take the familiar isoelastic form$

$$
u(f)=\frac{[f]^{\gamma}}{\gamma}, \quad \gamma<1
$$

Recalling that $\ell$ changes from $\bar{\ell} \in[0,1)$ to 1 at retirement, condition (3) at retirement date $t=R$ is

$$
\begin{gathered}
\left(\left[c_{R-}\right]^{\alpha} \cdot[\bar{\ell}]^{1-\alpha}\right)^{\gamma-1} \cdot \alpha \cdot\left[c_{R-}\right]^{\alpha-1} \cdot[\bar{\ell}]^{1-\alpha}=\left(\left[c_{R+}\right]^{\alpha}\right)^{\gamma-1} \cdot \alpha \cdot\left[c_{R+}\right]^{\alpha-1} \Longleftrightarrow \\
{\left[c_{R-}\right]^{\alpha \cdot \gamma-1} \cdot[\bar{\ell}]^{(1-\alpha) \cdot \gamma}=\left[c_{R+}\right]^{\alpha \cdot \gamma-1} \Longleftrightarrow} \\
{\left[c_{R-}\right] \cdot[\bar{\ell}]^{-\frac{\gamma \cdot(1-\alpha)}{1-\alpha \cdot \gamma}}=\left[c_{R+}\right] .}
\end{gathered}
$$

Equation (5) shows that the change in consumption at retirement provides useful information for estimating the parameter $\gamma$, which determines the IES. Specifically, given $\alpha$ and $\bar{\ell}$, the change in consumption at retirement pins down $\gamma$. It is straightforward to show that the change in consumption at retirement is strictly increasing in $\gamma$. In particular, if $\gamma$ is nearly $1, u($.$) is nearly linear; and we have noted that in this case consumption jumps$ up at retirement. More generally, whenever $0<\gamma$, consumption discontinuously rises at retirement:

$$
c_{R-}<c_{R+} \quad \text { if } \quad\left[\bar{\ell}^{-\frac{\gamma \cdot(1-\alpha)}{1-\alpha \cdot \gamma}}>1 \Longleftrightarrow-\frac{\gamma \cdot(1-\alpha)}{1-\alpha \cdot \gamma}<0 \Longleftrightarrow \gamma>0\right.
$$

On the other hand, the preceding algebra indicates that

$$
c_{R-}>c_{R+} \Longleftrightarrow \gamma<0
$$

Thus, whenever $\gamma<0$, the model predicts a discontinuous drop in consumption at retirement and, because $\left(c_{R+}-c_{R-}\right)$ is increasing in $\gamma$, the decline in consumption at retirement grows larger as the taste for intertemporal smoothing increases ( $\gamma$ decreases). 
To summarize, our analysis illustrates that an abrupt adjustment in consumption at retirement is consistent with rational behavior. Equation (5) also shows that data on the size of change in consumption can help us to identify the taste for intertemporal substitution. We now turn to this task of estimation.

\section{Model}

This section presents the model that is the basis for our empirical analysis. We first elaborate the framework above to facilitate comparisons with data as follows: we allow for changes in household size and composition that may influence households' preferences for consumption; and, we consider the possible role of liquidity constraints. Then we lay out our estimation strategy.

Equivalent Adults. To confront data, we take into account the fact that households gain and lose members over their life spans, and presumably desire greater consumption at ages when their membership is larger.

Following Tobin [1967], let the number of "equivalent adults" per household of age $t$ be $n_{t}$. Let $n_{t}$ satisfy

$$
n_{t}=1+\xi^{S} \cdot n_{t}^{S}+\xi^{C} \cdot n_{t}^{C},
$$

where the household's head constitutes one equivalent adult, $n_{t}^{S}$ is 1 if there is a spouse and 0 otherwise, $n_{t}^{C}$ is the number of children in the household, and $\xi^{S}$ and $\xi^{C}$ are equivalency weights (relative to the head's weight of 1). If a household's age- $t$ expenditure on consumption is $c_{t}$, let the household's corresponding flow of utility be

$$
n_{t} \cdot u\left(f\left(\frac{c_{t}}{n_{t}}, \ell_{t}\right)\right)
$$

The idea is that households internally allocate their lifetime resources "fairly." To understand the outcome, consider a household facing interest and subjective discount rates 
of zero and suppose that $\ell_{s}=\ell_{t}$. Then in our framework, the household would want to allocate budget $x$ between periods $s$ and $t$ to solve

$$
\begin{gathered}
\max _{c_{s}, c_{t}}\left\{n_{s} \cdot u\left(f\left(\frac{c_{s}}{n_{s}}, \ell_{s}\right)\right)+n_{t} \cdot u\left(f\left(\frac{c_{t}}{n_{t}}, \ell_{t}\right)\right)\right\} \\
\text { subject to: } c_{s}+c_{t} \leq x .
\end{gathered}
$$

When $u\left(f\left(., \ell_{s}\right)\right)$ is concave, a solution requires $c_{s} / n_{s}=c_{t} / n_{t}$; so, utility maximization implies

$$
c_{t}=\frac{n_{t}}{n_{s}} \cdot c_{s}
$$

In other words, if the household consists of the head alone at $s$, five members at $t$, and the latter constitute two equivalent adults, the household will allocate twice as much budget for consumption at $t$ as at $s$. If there are scale economies to household operation or public goods that household members can share, the weights on spouse and children will be less than 1. The smaller are $\xi^{S}$ and $\xi^{C}$, the larger the advantages of scale. We will estimate $\xi^{S}$ and $\xi^{C}$

Liquidity Constraints. A large literature studies the potential effects of liquidity constraints on life--cycle saving (e.g., Mariger [1986], Zeldes [1989], Hubbard and Judd [1986]). To analyze actual behavior, we separately consider two cases. In the first, financial markets are unwilling to extend loans without collateral; thus, if $a_{t}$ is household net worth at age $t$, we incorporate into our model a constraint

$$
a_{t} \geq 0 \text { all } t
$$

In the second case, we allow $a_{t}$ take any value (provided only that $a_{0}=a_{T}=0$ ). For example, it is conceivable that unsecured credit-card debt has, at least in the last several 
decades, enabled U.S. households to carry negative net worth balances. Or, inter vivos transfers from parents to their grown children might largely eliminate the effects of liquidity constraints.

Model. The life-cycle maximization model upon which we base our empirical analysis is as follows: for household $i$,

$$
\begin{gathered}
\max _{R_{i}, c_{i t}} \int_{0}^{T} e^{-\rho \cdot t} \cdot n_{i t} \cdot u\left(f\left(\frac{c_{i t}}{n_{i t}}, \ell_{i t}\right)\right) d t \\
\text { subject to: } \quad \ell_{i t}= \begin{cases}\bar{\ell}, & \text { for } t<R_{i} \\
1, & \text { for } t \geq R_{i}\end{cases} \\
\dot{a}_{i t}=r \cdot a_{i t}+\left(1-\ell_{i t}\right) \cdot e_{i t} \cdot w \cdot\left(1-\tau-\tau^{s s}\right)+s s b_{i t} \cdot(1-\tau / 2)-c_{i t}, \\
a_{i t} \geq 0 \quad \text { all } t, \\
a_{i 0}=0=a_{i T},
\end{gathered}
$$

where $\rho$ is the subjective discount rate, and equivalent adults, $n_{i t}$, come from (6). Household $i$ supplies $e_{i t}$ "effective hours" in the labor market per hour of work time; hence, if $w$ is the economy wide average wage rate, the household earns $e_{i s} \cdot w$ per hour of market work at age $s$. Earnings include both the wages of the head and those of the spouse, if present and working in the labor market. We assume a proportional income tax $\tau$ on earnings, interest, and one half of Social Security benefits, $s s b_{i t}$. The real interest rate $r$ is given in net-of-tax terms. There is also a proportional Social Security tax $\tau^{s s}$. As above, we take $f($.$) to be Cobb-Douglas and u($.$) to be isoelastic. In our first case, we incorporate$ 
liquidity constraint (8), as shown. In a second case, we analyze (9) omitting the constraint $a_{i t} \geq 0$ all $t$.

The isoelastic utility function $u($.$) is standard. Our Cobb-Douglas specification for$ $f($.$) has a number of advantages over a more general CES function that is sometimes used$ in the literature: it does not imply secular trends in the average retirement age due to technological progress; it is consistent with our aggregative approach in the sense that it does not lead households of different earning ability (i.e., different $e_{i t}$ in (9) at the same age t) to behave differently; and, it allows exact identification below without disaggregative data, time series variation in tax rates, etc.

Identification. This paper estimates two equations based on model (9). The first is the Euler equation from utility maximization with respect to consumption; the second stems from utility maximization with respect to retirement age. The parameters of ultimate interest form a vector

$$
\theta \equiv\left(\alpha, \gamma, \rho, \xi^{S}, \xi^{C}\right)
$$

With both estimating equations together, the elements of $\theta$ are exactly identified.

Euler equation. Suppose for a given retirement age $R_{i}$ that we solve (9) for the utilitymaximizing life-cycle time path of consumption. We then face a concave maximization problem with a convex constraint set. Liquidity constraint (8) introduces complications, but Mariger [1986] provides an algorithm. The algorithm divides a lifetime $[0, T]$ into a sequence of closed intervals $I_{i}$. On alternate intervals either the liquidity constraint binds, in which case $c_{t}$ equals the household's current resource inflow, or the constraint does not bind, in which case the Euler equation, described next, holds. In practice, in every case that we consider, the algorithm finds at most two intervals. In the last, the Euler equation holds; if there are two, the liquidity constraint binds in the first. For simplicity, henceforth 
our exposition assumes two intervals, $[0, S]$ and $[S, T]$, with $S<R_{i}$.

Consider $s \in\left[S, R_{i}\right)$. The arguments of Section 2 imply

$$
\frac{\partial n_{i S} \cdot u\left(f\left(\frac{c_{i S}}{n_{i S}}, \bar{\ell}\right)\right)}{\partial c_{i S}}=e^{(r-\rho) \cdot(s-S)} \cdot \frac{\partial n_{i s} \cdot u\left(f\left(\frac{c_{i s}}{n_{i s}}, \bar{\ell}\right)\right)}{\partial c_{i s}} .
$$

So,

$$
\frac{c_{i S}}{n_{i S}}=e^{\frac{-(r-\rho) \cdot(s-S)}{1-\alpha \cdot \gamma}} \cdot \frac{c_{i s}}{n_{i s}}
$$

In other words,

$$
c_{i s}=\psi_{i S} \cdot e^{\frac{(r-\rho) \cdot(s-S)}{1-\alpha \cdot \gamma}} \cdot n_{i s} \quad \text { with } \quad \psi_{i S} \equiv c_{i S} / n_{i S}
$$

The preceding expression, and the reasoning of (5), determine our consumption Euler equation:

$$
c_{i s}= \begin{cases}\psi_{i S} \cdot e^{\frac{r-\rho}{1-\alpha \cdot \gamma} \cdot(s-S)} \cdot n_{i s}, & \text { if } S \leq s<R_{i} \\ \psi_{i S} \cdot e^{\frac{r-\rho}{1-\alpha \cdot \gamma} \cdot(s-S)} \cdot n_{i s} \cdot[\bar{\ell}]^{\frac{-\gamma \cdot(1-\alpha)}{1-\alpha \cdot \gamma}}, & \text { if } s \geq R_{i} .\end{cases}
$$

Integrating the budget constraints of (9), setting

$$
c_{i s}=(1-\bar{\ell}) \cdot e_{i s} \cdot w \cdot\left(1-\tau-\tau^{s s}\right)
$$

for $s<S$, and setting $c_{i s}$ from (10) otherwise, we obtain

$$
\begin{gathered}
\psi_{i S}=\left[\int_{S}^{R_{i}} e^{-r \cdot t} \cdot(1-\bar{\ell}) \cdot e_{i t} \cdot w \cdot\left(1-\tau-\tau^{s s}\right) d t+\int_{R_{i}}^{T} e^{-r \cdot t} \cdot s s b_{i t} \cdot\left(1-\frac{\tau}{2}\right) d t\right] / \\
{\left[\int_{S}^{R_{i}} e^{-r \cdot t} \cdot e^{\frac{r-\rho}{1-\alpha \cdot \gamma} \cdot t} \cdot n_{i t} d t+\int_{R_{i}}^{T} e^{-r \cdot t} \cdot[\bar{\ell}]^{\frac{-\gamma \cdot(1-\alpha)}{1-\alpha \cdot \gamma}} \cdot e^{\frac{r-\rho}{1-\alpha \cdot \gamma} \cdot t} \cdot n_{i t} d t\right]}
\end{gathered}
$$


Thus, $\psi_{i S}$ reflects a household's entire life course — including its earning ability, number of children, and retirement age.

Our empirical specification takes logarithms of both sides of (10) and appends a term $\nu_{i s}$ to the right side to reflect consumption measurement errors. From (6),

$$
\ln \left(n_{i s}\right) \approx \xi^{S} \cdot n_{i s}^{S}+\xi^{C} \cdot n_{i s}^{C} .
$$

Writing (10) at $s \geq S$ and again at $s+1$, taking logs, and differencing, we have

$$
\begin{gathered}
\ln \left(c_{i, s+1}\right)-\ln \left(c_{i s}\right)=\frac{r-\rho}{1-\alpha \cdot \gamma}+\xi^{S} \cdot\left[n_{i, s+1}^{S}-n_{i s}^{S}\right]+\xi^{C} \cdot\left[n_{i, s+1}^{C}-n_{i s}^{C}\right]- \\
\frac{\gamma \cdot(1-\alpha)}{1-\alpha \cdot \gamma} \cdot \ln (\bar{\ell}) \cdot\left[\chi_{s+1}\left(R_{i}\right)-\chi_{s}\left(R_{i}\right)\right]+\nu_{i, s+1}-\nu_{i s},
\end{gathered}
$$

where we use the indicator function

$$
\chi_{s}(R) \equiv \begin{cases}0, & \text { if } s<R \\ 1, & \text { if } s \geq R .\end{cases}
$$

Differencing eliminates $\psi_{i S}$ from (11). Removing the influence of, among other things, varying earning abilities, is extremely convenient in practice - our Health and Retirement Study data provide lifetime earning records for only one cohort of households, and, although we have Consumer Expenditure Survey consumption data for many cohorts, the latter data's overlap with the cohort having complete earning information is short. Section 4 estimates (11) as a linear regression equation.

Optimal retirement age. The four coefficients of difference equation (11) are composites of the five structural parameters of the underlying model: letting the vector $\beta$ denote the coefficients of (11), we have 


$$
\beta \equiv\left(\beta_{1}, \beta_{2}, \beta_{3}, \beta_{4}\right) \equiv\left(\frac{r-\rho}{1-\alpha \cdot \gamma}, \xi^{S}, \xi^{C},-\frac{\gamma \cdot(1-\alpha) \cdot \ln (\bar{\ell})}{1-\alpha \cdot \gamma}\right)
$$

Even if we have estimated $\beta$, we need one more condition to identify $\alpha, \gamma$, and $\rho$ separately. To complete our identification, we turn to a second equation stemming from maximization of (9) with respect to retirement age $R_{i}$.

For any parameter vector $\theta$, one can solve model (9) for a household's optimal retirement age. After maximizing (9) with respect to consumption — our Euler-equation step above - call the criterion $V\left(R_{i}\right)$. Our next step chooses the $R$ which maximizes $V(R)$. Although $V($.$) may not be concave, our numerical calculation maximizes V(R)$ by trying every monthly retirement age from 0 to $T \cdot{ }^{7}$ Denote the optimal retirement age as $g(\theta)$. Given our functional forms, even if households have different wage rates, reflecting different inherent earning abilities, their desired retirement ages are the same. Preferred retirement ages could, nevertheless, differ in practice because households anticipate differences in longevity due to heredity; households have differing numbers of children; occupations differ in their physical and emotional stress, leading to occupational differences in $e_{i t}$ at advanced ages; households have different health status; households have differing tastes for leisure; etc. To model possible variations in preferences, health, and demography, we could modify the lifetime utility function of (9) to

$$
\int_{0}^{T} e^{-\rho \cdot t} \cdot n_{i t} \cdot u\left(f\left(\frac{c_{i t}}{n_{i t}}, \ell_{i t}\right)\right) d t+\varphi_{i} \cdot \int_{R_{i}}^{T} d t
$$

where $\varphi_{i}$ is positive (negative) if household $i$ has an unusually strong (weak) induced

7 Having found the best month in a discrete choice space, for increased computational accuracy we then solve the first-order condition $V^{\prime}(R)=0$ - for the local maximum. A derivation of the first-order condition is available from the authors on request. 
preference for leisure. The optimal retirement age is then

$$
R_{i}=g(\theta)+\eta_{i}
$$

where $R_{i}$ is the household's actual retirement age, and $\eta_{i}$ is a random error reflecting deviations from average in $\varphi_{i}$.

Estimating the Structural Parameters Suppose our Euler equation generates an estimate $\hat{\beta}$ of vector $\beta$. We calibrate $\bar{\ell}$ below. Letting $x \equiv-\beta_{4} / \ln (\bar{\ell})$, the fourth term of (12) yields

$$
x=\frac{\gamma-\alpha \cdot \gamma}{1-\alpha \cdot \gamma} \Longleftrightarrow \gamma=\frac{x}{(x-1) \cdot \alpha+1} .
$$

If we knew $\alpha,(14)$ would determine $\gamma$. The first term in (12) would then pin down $\rho$.

Our strategy is as follows. We estimate $\hat{\beta}$ from consumption Euler equation (11). Then expression (14) shows that $\theta=\theta(\alpha, \hat{\beta})$. Combining the latter with (13), we estimate $\alpha$ from a regression of

$$
R_{i}=g(\theta(\alpha, \hat{\beta}))+\eta_{i}
$$

Fortunately, one can expect to be able to match any retirement age $R_{i}$ with an $\alpha \in[0,1]$. For example, if $\alpha=0$, leisure but not consumption yields utility; so, households would choose never to work at all. If $\alpha=1$, on the other hand, consumption but not leisure yields utility; so, households would choose never to retire.

\section{Consumption}

We estimate the parameter composites of expression (12) from a GLS linear regression on equation (11). This section describes our data and results.

CEX Data. The primary data source for this section is the U.S. Consumer Expenditure Survey (CEX). It is the most comprehensive source of disaggregate consumption data for 
the U.S. The CEX obtains diary information on small purchases from one set of households; for a second set of households, it conducts quarterly interviews that catalog major purchases. The survey also collects demographic data and data on value of the respondent's house. At any given time, the sample consists of approximately 5,000 (7,000 after 1999) households each of which remains in the survey for at most 5 quarters. The survey was conducted at multi-year intervals prior to 1984, and annually thereafter. This paper uses the CEX surveys from 1984-2001. ${ }^{8}$

Table 1 compares National Income and Product Account (NIPA) personal consumption for 1985, 1990, 1995, and 2000 with weighted totals from the CEX. ${ }^{9}$ We exclude household expenditures on pensions and life insurance from the CEX: the former constitute saving, and our concept of earnings is net of insurance. Looking at the last row of Table 1, total consumption measured in the CEX is only about 50-70 percent as large as the NIPA equivalent, with the discrepancy higher in later years. ${ }^{10}$ This paper assumes that the NIPA numbers are accurate; that item-nonresponse and other measurement errors of the survey typically make CEX totals too low; and, that the relative magnitude of survey errors does not systematically vary with age. Thus, for each year we scale CEX consump-

8 The web site http://stats.bls.gov.gov/csxhome.htm presents aggregative tables, codebooks, etc., for the CEX. This paper uses raw CEX data from the ICPSR archive, and we gratefully acknowledge the assistance of the BLS in providing stub files of changing category definitions.

9 We abstract from the empirical difference between consumption and expenditure (e.g., Aguiar and Hurst [2004]). Except in the case of housing, this paper draws no distinction between consumer durable stocks and flows.

10 There is a particularly large gap for "apparel" in 1985 . The 1984 and 1985 data files omit a number of apparel subcategories. We assume this does not create biases with respect to age — so that our scaling procedure below is sufficient to eliminate the problem. 
tion categories, uniformly across ages, to match NIPA amounts. Appendix I describes in detail three additional adjustments concerning the treatment of housing services, health care, and personal business expenditures.

\begin{tabular}{|c|c|c|c|c|}
\hline \multicolumn{5}{|c|}{$\begin{array}{c}\text { Table 1. Consumer Expenditure Amount } \div \text { NIPA Amoun } \\
{\text { (percent })^{a}}^{(\text {Nat }}\end{array}$} \\
\hline Category & 1985 & 1990 & 1995 & 2000 \\
\hline food & 73.5 & 69.6 & 64.9 & 62.3 \\
\hline apparel & 22.0 & 60.0 & 55.4 & 49.5 \\
\hline personal care & 73.7 & 65.8 & 61.7 & 70.2 \\
\hline shelter: & 82.9 & 82.4 & 81.4 & 81.0 \\
\hline own home & 74.1 & 69.7 & 73.0 & 71.4 \\
\hline other & 102.1 & 112.2 & 102.5 & 107.6 \\
\hline household operation & 76.0 & 82.6 & 78.6 & 71.4 \\
\hline transportation & 111.7 & 109.0 & 110.7 & 105.4 \\
\hline medical care & 27.6 & 23.2 & 20.1 & 19.3 \\
\hline recreation & 61.8 & 55.5 & 50.9 & 45.0 \\
\hline education & 65.1 & 61.2 & 58.8 & 57.4 \\
\hline personal business: & 14.8 & 12.2 & 9.9 & 6.8 \\
\hline brokerage fees & 0.0 & 0.0 & 0.0 & 0.0 \\
\hline other & 48.5 & 37.5 & 33.0 & 23.4 \\
\hline miscellaneous & 120.0 & 80.0 & 68.0 & 67.5 \\
\hline total & 66.7 & 64.3 & 59.7 & 56.0 \\
\hline
\end{tabular}

a. Source: http://www.bea.doc.gov/bea/dn/nipaweb/AllTables.asp, Section 2, Table 2.4.

Deflating with the NIPA personal consumption deflator, we derive an adjusted consumption amount for each age $i$ and year $t$. This is our measure of $c_{i t}$. Due to the construction of the CEX from separate interview and diary surveys, we do not have consumption figures for individual households; however, we can form a pseudo panel of average household consumption for each age and year. The number of interviewed households per cell that we use below varies from 127 to 981 . The left-hand side variable for our Euler 
equation is

$$
\Delta \ln \left(c_{i t}\right) \equiv \ln \left(c_{i+1, t+1}\right)-\ln \left(c_{i t}\right) .
$$

We organize the data so that a household's age is the age of the wife for a married couple, and the age of the single household head in other cases.

The CEX provides information on whether the household is married. The latter provides our regressor $n^{S} \in\{0,1\}$. Although the CEX also reports number of children ages $0-17$, we are interested in the consumption of older children; hence, we construct our own measure of children per household as follows. Using Census data on births per woman at age $i, i \in\{15, \ldots, 49\}$, in year $t \in\{1920, \ldots, 2001\}$, we simulate the number of children of each age for women of separate ages $i$ in $1984, \ldots, 2001 .^{11}$ As stated, our data set assigns household observations to each age cell according to the age of the adult woman for all but single male households. We append numbers of children to each cell on the basis of the ages and birth dates of women.

Similarly, the CEX survey questions on retirement are not ideal for our purposes. The CEX interview questionnaire (e.g., http://stats.bls.gov/cex/csxce30201.pdf) only asks whether the respondent is "retired" if he or she had zero weeks of work in the last twelve months; therefore, we turn to the March Current Population Survey 1984-2001 for our

11 The natality statistics for 1920-40 come from http://www.cdc.gov/nchs/products/pubs/pubd/vsus/1963/1963.htm, Vital Statistical Rates In The U.S. 1900-1940. Statistics for 1940-1999 come from http://www.cdc.gov/nchs/datawh/statab/unpubd/natality/natab99.htm, Table 1-7: Total Fertility Rates and Birth Rates, By Age of Mother and Race: US, 1940-99. Data for 1999-2001 come from http://www.cdc.gov/nchs/births.htm. 
$\chi_{s}\left(R_{i}\right)$ variable. ${ }^{12,13}$ We consider a household retired if the head is at least 50 years old and answers that he or she is out of the labor force at the time of the March survey. For male-female couples, the household is retired for our purposes if the male is at least 50 and out of the labor market (in the March survey). We focus on male behavior because males were more attached to the labor force in the cohorts of our data that reach retirement age, and because our analysis abstracts from a detailed model of decision making within dual earner households and home-work/market-work choices.

Regression Results. Tables 2-3 present regression results for (11). We use households of age 20-80 for 1984-2001, so that our differences $\Delta \ln \left(c_{i t}\right)$ cover ages 20-79 and years 19842000. Each regression includes separate time dummies for $1984,1985, \ldots, 1999$. The other independent variables are a constant; presence of a spouse, $n^{S}$; retirement status, $\chi(R)$; and, number of children $0-22, n^{C}$.

Table 2 provides our estimates of $\beta=\left(\beta_{1}, \ldots, \beta_{4}\right)$. The first column includes households as young as 20, but we worry that liquidity constraints may bind at the early ages. When constraints bind, household consumption grows at the same rate as earnings - and faster than the Euler equation dictates. Columns 2-4 successively exclude ages under 25, 30, and 35. The estimates in columns 2-4 differ substantially from those of column 1 but not from one another.

Table 3 considers liquidity constraints more systematically. It incorporates all age groups, but it includes separate dummy variables for ages 20-34. If liquidity constraints bind in practice at a given age, we expect the corresponding dummy variable to have a

12 These data were downloaded using the University of Michigan's Population Studies Center CPS extract utility: http://www.psc.isr.umich.edu/dads/inhouse/extract.html. 13 The average median retirement age 1984-2001 in the CEX data is 64-65, whereas it is about 62 in the Current Population Survey over the same period. See also our HRS results in Section 5 below. 


\section{Table 2. Estimated Coefficients for Consumption Euler Equation: Consumer Expenditure Survey Data 1984-2000 ${ }^{a}$}

\begin{tabular}{|c|c|c|c|c|}
\hline \multirow{2}{*}{ Parameter } & \multicolumn{4}{|c|}{ Consumer Expenditure Survey Sample Ages: ${ }^{b}$} \\
\hline & $\begin{array}{c}\text { Age } \\
20-79\end{array}$ & $\begin{array}{c}\text { Age } \\
25-79\end{array}$ & $\begin{array}{c}\text { Age } \\
30-79\end{array}$ & $\begin{array}{c}\text { Age } \\
35-79\end{array}$ \\
\hline $\begin{array}{c}\text { Constant } \\
\text { (S.E.) } \\
\text { T Stat. }\end{array}$ & $\begin{array}{c}0.0275 \\
(0.0009) \\
30.2060\end{array}$ & $\begin{array}{c}0.0259 \\
(0.0010) \\
27.1764\end{array}$ & $\begin{array}{c}0.0261 \\
(0.0012) \\
21.2747\end{array}$ & $\begin{array}{c}0.0249 \\
(0.0018) \\
14.0274\end{array}$ \\
\hline $\begin{array}{c}\text { Spouse } \\
\text { S.E. } \\
\text { T Stat. }\end{array}$ & $\begin{array}{c}0.6112 \\
(0.0397) \\
15.3805\end{array}$ & $\begin{array}{c}0.4351 \\
(0.0460) \\
9.4498\end{array}$ & $\begin{array}{c}0.4441 \\
(0.0528) \\
8.4139\end{array}$ & $\begin{array}{c}0.4336 \\
(0.0606) \\
7.1553\end{array}$ \\
\hline $\begin{array}{c}\text { Retired } \\
\text { S.E. } \\
\text { T Stat. }\end{array}$ & $\begin{array}{c}-0.1283 \\
(0.0325) \\
-3.9499\end{array}$ & $\begin{array}{c}-0.1595 \\
(0.0313) \\
-5.0914\end{array}$ & $\begin{array}{c}-0.1602 \\
(0.0332) \\
-4.8198\end{array}$ & $\begin{array}{c}-0.1387 \\
(0.0390) \\
-3.5529\end{array}$ \\
\hline $\begin{array}{c}\text { Child 0-22 } \\
\text { S.E. } \\
\text { T Stat. }\end{array}$ & $\begin{array}{c}0.1452 \\
(0.0074) \\
19.4908\end{array}$ & $\begin{array}{c}0.1346 \\
(0.0078) \\
17.2704\end{array}$ & $\begin{array}{c}0.1370 \\
(0.0103) \\
13.3255\end{array}$ & $\begin{array}{c}0.1290 \\
(0.0139) \\
9.2761\end{array}$ \\
\hline \multicolumn{5}{|c|}{ Summary Statistics } \\
\hline$R^{2}$ & 9.8010 & 8.2234 & 7.1227 & 7.4512 \\
\hline Observations & 1020 & 935 & 850 & 765 \\
\hline Mean Sq Error & 0.0086 & 0.0082 & 0.0087 & 0.0091 \\
\hline
\end{tabular}

a. Year dummies 1984, 1985, ... 1999 not reported.

b. For couples, age of adult female - see text.

positive coefficient. The first dummy-variable coefficients are indeed large and significantly different from zero; however, the effect seems to run its course by age 25 .

In the end, we restrict our attention to Euler-equation estimates from columns 2-4 of Table 2. If liquidity constraints are not important in practice, using only columns 2-4 sacrifices some valid data; however, if constraints do bind for households but we nevertheless use column 1, our estimates will be inconsistent.

Consider the third column of Table 2. The constant implies an average lifetime growth 
Table 3. Specification Analysis: Consumption Euler Equation, CEX Data Years 1984-2000 and Female Ages 20-79, Dummy Variable each Age 20-34 ${ }^{a}$

\begin{tabular}{|c|c|c|}
\hline Parameter & Coefficient & T Stat \\
\hline \multicolumn{3}{|c|}{ Independent Variables as in Table 3} \\
\hline Constant & 0.0249 & 15.7120 \\
\hline Spouse & 0.4132 & 7.9061 \\
\hline Retired & -0.1462 & -4.0465 \\
\hline Child $0-22$ & 0.1265 & 9.8395 \\
\hline \multicolumn{3}{|c|}{ New Dummy Variables for Female Ages 20-34 } \\
\hline Age 20 & 0.0638 & 2.6621 \\
\hline Age 21 & 0.1149 & 4.7912 \\
\hline Age 22 & 0.0419 & 1.7620 \\
\hline Age 23 & -0.0083 & -0.3461 \\
\hline Age 24 & 0.0299 & 1.2659 \\
\hline Age 25 & -0.0122 & -0.5139 \\
\hline Age 26 & -0.0086 & -0.3660 \\
\hline Age 27 & 0.0090 & 0.3806 \\
\hline Age 28 & -0.0070 & -0.2963 \\
\hline Age 29 & 0.0014 & 0.0580 \\
\hline Age 30 & 0.0126 & 0.5383 \\
\hline Age 31 & -0.0172 & -0.7328 \\
\hline Age 32 & -0.0042 & -0.1800 \\
\hline Age 33 & 0.0343 & 1.4619 \\
\hline Age 34 & -0.0070 & -0.3655 \\
\hline
\end{tabular}

a. Year dummies 1984, 1985, ..., 1999 not reported.

rate for per capita consumption of $2.6 \% / \mathrm{yr}$. That suggests that between, say, ages 25 and 62 , in the absence of retirement a household's consumption per equivalent adult would rise by a factor of 2.62. In Auerbach and Kotlikoff [1987], for instance, the corresponding factor is about 1.54; in Gokhale et al. [2001], it is 1.74; in Tobin [1967], it is 13.33. For an infinite-lived representative agent model (e.g., Cooley and Prescott [1995]), the growth rate of consumption in a steady-state equilibrium would, of course, match the growth rate 
of GDP.

We estimate that the addition of a spouse raises household consumption by 44 percent. This closely agrees with the U.S. Social Security System's award of 50 percent extra benefits for a spouse. Our estimate implies substantial returns to scale for larger households. Many papers in the literature set $\xi^{S}=1.0$, and Table 2 suggests that such a calibration may be misleading.

Column 3 estimates a 16 percent drop in consumption at retirement. This is consistent with, though at the smaller end of, estimates in Bernheim et al. [2001], Banks et al. [1998], and Hurd and Rohwedder [2003] and the retirement brochures cited in Laitner [2001]. ${ }^{14}$

While our estimate of the decline in expenditure at retirement is relatively modest, it may still represent an overestimate if the timing of retirement is, to some extent, unanticipated and disproportionately driven by shocks that decrease lifetime income. Our certainty equivalent model assumes that the relevant risk is fully insured and therefore does not affect the shape of the age-consumption profile. In reality, however, there may be uninsured shocks. Unanticipated retirements driven by positive shocks to health or asset returns, and therefore lifetime income, would likely be associated with discrete increases in consumption. These cases would tend to bias our estimate of the anticipated change in consumption at retirement upwards. Conversely, retirements driven by negative, uninsured shocks would likely be associated with discrete decreases in consumption. To the extent that retirement is unanticipated, and disproportionately driven by shocks that lower expected lifetime income, our estimates would overstate the degree to which the decline in consumption at retirement derives from the nonseparability of consumption and leisure.

The non-zero coefficient and large t statistic on "Retired" in Table 3 reject intratem-

14 Earlier drafts of this paper with less disaggregate treatment of medical expenditures (recall Appendix I) implied declines of 20 percent or more, but we believe that our current specification is more accurate. 
poral additive separability of consumption and leisure - and Section 2 shows that the rejection does not heavily depend upon the form of our production function.

Table 3's fourth row indicates an increase in household consumption of 14 percent for each child age 0-22. Since two parents correspond to 1.44 "equivalent adults," a child adds about 20 percent as much as each parent. Mariger [1986] estimates that children consume 30 percent as much as adults; Attanasio and Browning [1995, p. 1122] suggest 58 percent; Gokhale et al. [2001] assume 40 percent; most of the analysis in Auerbach and Kotlikoff [1987] implicitly weights children at zero; Tobin [1967] assumes teens consume 80 percent as much as adults, and minor children 60 percent.

One would expect that estimating the coefficient for children would be difficult. Although the date at which a child enters a household is precise, in practice different children leave home at different ages. Unfortunately, liquidity constraints may bind exactly when many children are born (recall that our Euler equation only perceives changes in numbers of children). Nevertheless, our estimated coefficients on "Child 0-22" have small standard errors and large $t$ statistics. Our treatment does not, of course, measure reductions in parental market work hours due to children. Although this omission surely affects one's interpretation of our coefficients, Section 5's earning profiles do reflect women's actual labor force participation and hours - so this margin of choice enters our analysis in another way. It may be true as well that parents spend a great deal on children but simultaneously reduce expenditures on themselves, vicariously enjoying their children's consumption. The latter would not invalidate our analysis, but it might, again, suggest a different interpretation of the "cost" of children.

One might worry that economywide shocks could affect both general retirement behavior and consumption. Our regressions include year dummies - and they have little effect on the coefficients of primary interest. Because macroeconomic shocks conceivably affect consumption differently at different ages, we also perform GLS on a version of (11) 
in which we average every variable at each age over all years. Although the t statistics drop because the number of degrees of freedom falls almost 95 percent, the coefficient estimates reconfirm Table 2: for ages 20-79, the new coefficient estimates are, for the constant, spouse, retired, and child variables, respectively, 0.0276, 0.8398, -0.0698, 0.1367; for ages $25-79$, they are $0.0258,0.4481,-0.1625,0.1332$; for ages $30-79$, they are $0.0253,0.4318$, $-0.1589,0.1298$; and, for ages $35-79$, they are $0.0230,0.3025,-0.1507,0.1137$.

\section{Retirement}

We employ equation (15) to complete the estimation our model's structural parameters. To determine the utility-maximizing retirement age for (15) from our model, we need to specify earnings profiles, taxes, and interest rates; for the dependent variable of a regression of (15), we need empirical retirement ages. For both earning profiles and empirical retirement ages, this section turns to our second major data source, the Health and Retirement Study (HRS).

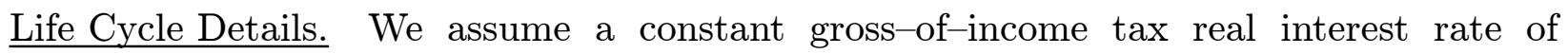
$5 \% /$ yr. $^{15}$

15 Our real interest rate comes from a ratio of factor payments to capital over the market value of private net worth. For the numerator, NIPA Table 1.13 gives corporate business income, indirect taxes, and total labor compensation. The first less the other two is our measure of corporate profits; the ratio of profits to profits plus labor remuneration is "profits share." We multiply the latter times corporate, noncorporate, and nonprofitinstitution income less indirect taxes. We add household-sector income (NIPA Table 1.13) less indirect taxes and labor remumeration. Finally, we subtract personal business expenses (brokerage fees, etc. from NIPA Table 2.5.5, rows 61-64). The denominator is U.S. Flow of Funds household and non-profit institution net worth (Table B.100, row 19), less government liabilities (Table L106c, row 20). We average beginning and end 
We disregard government transfer payments besides Social Security. Our income tax rate $\tau$ comes from government spending on goods and services less indirect taxes (already removed from profits, and implicitly absent from wages and salaries below). Dividing by national income, the average over $1952-2003$ is $14.28 \%$ year. $^{16}$

We assume a payroll tax of $15.3 \%$ per year. One-half of Social Security benefits are subject to the income tax. In the calculations below, the Social Security benefit formula, including the ceiling on taxable annual earnings, follows the history of the U.S. system.

We assume that adults work 40 hours per week until retirement and 0 hours per week after retirement. With $16 \times 7$ waking hours per week, we set ${ }^{17}$

$$
\bar{\ell}=\frac{16 \times 7-40}{16 \times 7}=.6429
$$

Our retirement-age calculation uses a representative household consisting of a husband, wife, and two children. The wife reaches age 65 in the year 2000; the husband is 2 years older; the husband starts work at age 22 and marries at 24 , with the latter being the time at which the household begins; both children are born two years after the marriage; and, both children leave home at age $22 .{ }^{18}$ Following U.S. mortality tables, the husband dies at the end of age 74 ; the wife dies at the end of age 80 . All of our calculations use 2000 dollars; our price index is the NIPA consumption deflator.

of year figures. The average ratio 1952-2003 is .0504. For comparison, Auerbach and Kotlikoff [1987] use 6.7\%/year, Altig et al. [2001] 8.3\%/yr., Cooley and Prescott [1995] 7.2\%/yr., and Gokhale et al. [2001] use post-tax rates of 4\%/yr. and 6\%/yr.

16 Auerbach and Kotlikoff [1987], for example, use 15\%/year.

17 See also Cooley and Prescott [1995] — who, on the basis of time-use studies, determine that households devote $1 / 3$ of waking hours to work.

18 Notice that assuming two children per household produces a rough match with recent, slow U.S. population growth. 
We derive earnings profiles and retirement ages from the original HRS survey cohort, consisting of households in which the respondent is age 51-61 in 1992. A majority of participant households signed a permission waiver allowing the HRS to link to their Social Security Administration (SSA) earnings history. Each history runs 1951-1991; the HRS itself covers 1992, 1994, 1996, 1998, 2000, and 2002. In this paper, we use the HRS and linked SSA records. For men, we estimate a so-called earnings dynamics model regressing log earnings on a quadratic in age and dummy variables for time. Our regression error has an individual effect as well as a random term. The data is right censored at the Social Security tax cap prior to 1980 and the Medicare tax cap 1980-1991, and our likelihood function takes this into account. Assuming full-time work until retirement (and no work thereafter), we predict an average earnings profile for a man who reaches 65 in 1998 . Table A1, Appendix II, presents predicted annual earnings. For women, we use the same type of statistical model to predict earnings above the censoring limit. To allow for women's part-time work and absence at some ages from the labor force, we compute average earnings in all other cases from the actual data. We then use the regression time dummies to deduce an average earnings profile for women who reach 65 in 2000. Again, see Table A1. Finally, since HRS earnings are net of employer benefits (including health insurance, pension contributions, and employer Social Security tax), we multiply household earnings for each year by the ratio of NIPA total compensation to NIPA wages and salaries.

We derive Social Security benefits after retirement from the statutory benefit formula for 2000. Table A1, Appendix II, shows household benefits if the male retires at age 62 and his wife retires simultaneously, at age 60 . Given our treatment of consumption, we must also incorporate a stream of Medicare benefits after age 65, less participant SMI cost. To do this, for each adult 65 and older, we add to household resources Medicare benefits equaling the SMI annual premium for 2000 (i.e., $\$ 546$ ) multiplied by the ratio of HI and SMI total expenditures to SMI premiums for 2000 (i.e., 10.7282, less 1). Again, 
see Table A1.

Mean retirement age. We use the HRS as our source for empirical retirement ages; and, for reasons described above we focus on male retirement. Measuring the empirical average (male) age of retirement for this cohort is not entirely straightforward because the retirement date of many respondents is not observed. Even in the 2002 wave of the HRS, not all men have retired, and many men die or leave the survey before retiring. It follows that an average of the retirement ages among only those observed to have retired will yield a biased estimate of the population mean.

We use a censored regression to extract an unbiased estimate. Of the 6214 men who appear in one or more waves of the HRS, 727 retire before age 50 or provide insufficient information for our analysis. Excluding these, the sample is 5487. Among the latter, 3661 retire by the last available HRS wave, 2002. Their mean retirement age is 60.25 . The remaining 1826 men either (i) died before retiring, (ii) left the survey before retiring, or (iii) continued to work as of the last interview in 2002. Our analysis treats the 1826 men as right-censored at their age of death or last interview. The regression equation is

$$
R_{i}=\mu+\eta_{i},
$$

with dependent variable and error as in (15). Table 4 presents our estimate of the average retirement age, $\hat{\mu}=62.57$.

Structural Parameter Estimates. Although the preceding discussion might seem to suggest that we need to estimate (15) using a Tobit likelihood function, we can achieve exactly the same outcome with a two-step procedure as follows: estimate $\hat{\mu}$ from (16); then solve for the alpha, $\hat{\alpha}$, that satisfies

$$
\hat{\mu}=g(\theta(\alpha, \hat{\beta})) .
$$




\begin{tabular}{|c|c|c|c|}
\hline \multicolumn{4}{|c|}{ Table 4. Censored-Regression Output: } \\
Average Age of Retirement for HRS Males \\
\hline Variable & Value & Std. Err. & T-Stat \\
\hline Constant & 62.5747 & .0831 & 752.92 \\
\hline$\sigma_{\eta}$ & 5.5782 & .0669 & \\
\hline \multicolumn{3}{|c|}{ Summary Statistics } \\
\hline Log Likelihood & -12722.884 \\
\hline Uncensored Obs. & 3661 \\
\hline Censored Obs. & \multicolumn{3}{|c|}{1826} \\
\hline
\end{tabular}

a. See text.

Our estimate of theta is $\hat{\theta}=\theta(\hat{\alpha}, \hat{\beta})$. The so-called delta method - which uses the estimated covariance matrix for $\hat{\beta}$ and the estimated variance for $\hat{\mu}-$ yields an estimate of the asymptotic covariance matrix for $\hat{\theta}$.

Table 5 presents our estimates of the structural parameters, with and without liquidity constraint (8). The estimates of gamma vary from -.49 to -.58; the estimates of alpha vary from .27 to .28 . These correspond to estimates of an IES for services, $1 /(1-\gamma)$, of 0.63 to 0.67 and an IES for consumption itself, $1 /(1-\alpha \cdot \gamma)$, of 0.86 to 0.88 . The estimates of the subjective time discount rate, $\rho$, fall between .0117 and .0139 . All are statistically different from zero at the 5 percent significance level. As explained above, we favor Euler-equation estimates that employ data only for ages 25 and beyond; consequently, Table 5 presents results based on Table 2 coefficients for samples with ages $25-79,30-79$, and 35-79. The bottom panel of Table 5 shows that liquidity constraint (8) makes little difference to our estimation.

As noted in the introduction, our estimates of gamma, alpha, and rho are similar to a number of calibrations in the literature. For example, Auerbach and Kotlikoff's [1987] 
Table 5. Structural Parameters: Combine Consumption-Euler Equation Coefficients (Table 2) and Retirement-Age Estimate from HRS (Table 4) ${ }^{a}$

\begin{tabular}{|c|c|c|c|}
\hline \multirow{2}{*}{$\begin{array}{c}\text { Struc- } \\
\text { tural } \\
\text { Para- } \\
\text { meter }\end{array}$} & \multicolumn{3}{|c|}{ Consumption Regression Sample: } \\
\hline & $\begin{array}{c}\text { Female } \\
\text { Age } 25-79\end{array}$ & $\begin{array}{c}\text { Female } \\
\text { Age } 30-79\end{array}$ & $\begin{array}{c}\text { Female } \\
\text { Age 35-79 }\end{array}$ \\
\hline \multicolumn{4}{|c|}{ Formulation with Liquidity Constraint (8) } \\
\hline $\begin{array}{c}\text { Gamma } \\
\text { (S.E.) } \\
{[95 \% \text { Confid. }]}\end{array}$ & $\begin{array}{c}-0.5840 \\
(0.1320) \\
{[-0.8428,-0.3252]}\end{array}$ & $\begin{array}{c}-0.5874 \\
(0.1407) \\
{[-0.8631,-0.3117]}\end{array}$ & $\begin{array}{c}-0.4969 \\
(0.1589) \\
{[-0.8082,-0.1855]}\end{array}$ \\
\hline $\begin{array}{c}\text { Alpha } \\
\text { (S.E.) } \\
\text { [95\% Confid.] }\end{array}$ & $\begin{array}{c}0.280 \\
(0.0027) \\
{[0.2754,0.2858]}\end{array}$ & $\begin{array}{c}0.2809 \\
(0.0029) \\
{[0.2752,0.2866]}\end{array}$ & $\begin{array}{c}0.2802 \\
(0.0033) \\
{[0.2738,0.2867]}\end{array}$ \\
\hline $\begin{array}{c}\text { Rho } \\
\text { (S.E.) } \\
{[95 \% \text { Confid. }]}\end{array}$ & $\begin{array}{c}0.0119 \\
(0.0017) \\
{[0.0086,0.0153]}\end{array}$ & $\begin{array}{c}0.0117 \\
(0.0021) \\
{[0.0076,0.0158]}\end{array}$ & $\begin{array}{c}0.0137 \\
(0.0028) \\
{[0.0081,0.0193]}\end{array}$ \\
\hline $\begin{array}{c}\text { Alpha*Gamma } \\
\text { (S.E.) } \\
\text { [95\% Confid. }]\end{array}$ & $\begin{array}{c}-0.1639 \\
(0.0964) \\
{[-0.3528,0.0250]}\end{array}$ & $\begin{array}{c}-0.1650 \\
(0.1027) \\
{[-0.3662,0.0362]}\end{array}$ & $\begin{array}{c}-0.1392 \\
(0.1207) \\
{[-0.3759,0.0974]}\end{array}$ \\
\hline \multicolumn{4}{|c|}{ Addendum: Female Age Last Binding Liquidity Constraint (Simulated) } \\
\hline$($ Yr, Mth) & $(30,11)$ & $(30,11)$ & $(30,11)$ \\
\hline \multicolumn{4}{|c|}{ Formulation Omitting Liquidity Constraint (8) } \\
\hline $\begin{array}{c}\text { Gamma } \\
\text { (S.E.) } \\
{[95 \% \text { Confid. }]}\end{array}$ & $\begin{array}{c}-0.5741 \\
(0.1291) \\
{[-0.8272,-0.3210]}\end{array}$ & $\begin{array}{c}-0.5776 \\
(0.1376) \\
{[-0.8477,-0.3076]}\end{array}$ & $\begin{array}{c}-0.4881 \\
(0.1558) \\
{[-0.7936,-0.1827]}\end{array}$ \\
\hline $\begin{array}{c}\text { Alpha } \\
\text { (S.E.) } \\
{[95 \% \text { Confid. }]}\end{array}$ & $\begin{array}{c}0.2728 \\
(0.0034) \\
{[0.2662,0.2794]}\end{array}$ & $\begin{array}{c}0.2732 \\
(0.0038) \\
{[0.2657,0.2808]}\end{array}$ & $\begin{array}{c}0.2716 \\
(0.0046) \\
{[0.2626,0.2806]}\end{array}$ \\
\hline $\begin{array}{c}\text { Rho } \\
\text { (S.E.) } \\
{[95 \% \text { Confid. }]}\end{array}$ & $\begin{array}{c}0.0121 \\
(0.0017) \\
{[0.0088,0.0155]}\end{array}$ & $\begin{array}{c}0.0119 \\
(0.0021) \\
{[0.0078,0.0159]}\end{array}$ & $\begin{array}{c}0.0139 \\
(0.0028) \\
{[0.0084,0.0194]}\end{array}$ \\
\hline $\begin{array}{c}\text { Alpha*Gamma } \\
\text { (S.E.) } \\
{[95 \% \text { Confid. }]}\end{array}$ & $\begin{array}{c}-0.1566 \\
(0.0943) \\
{[-0.3415,0.0283]}\end{array}$ & $\begin{array}{c}-0.1578 \\
(0.1007) \\
{[-0.3552,0.0396]}\end{array}$ & $\begin{array}{c}-0.1326 \\
(0.1188) \\
{[-0.3654,0.1002]}\end{array}$ \\
\hline \multicolumn{4}{|c|}{ Addendum: Lowest Simulated Net Worth (Excluding Capitalized Social Security Benefits) } \\
\hline YR 2000 Dollars & $-36,861$ & $-36,088$ & $-40,406$ \\
\hline
\end{tabular}

a. See text. 
favorite calibration has $\gamma=-3, \alpha$ (roughly) $=.4$, and $\rho=.015$; Altig et al. [2001] use $\gamma=-3, \alpha$ (roughly) $=.5$, and $\rho=.004$; and, Cooley and Prescott [1995] set $\gamma=0$, $\alpha=.36$, and $\rho=.053$.

Our results may be compared with estimates that have identified the IES from expected changes interest rates. Using aggregate consumption data Hall [1988], Cambell and Mankiw [1989], and Patterson and Pesaran [1992], for example, estimate the IES for consumption to be very nearly zero. Micro studies tend to estimate larger intertemporal elasticities. Banks et al. [1998], for instance, estimate the average IES for consumption to be approximately 0.5. In another example, Attanasio and Weber [1993] estimate an IES for consumption of approximately 0.75 from micro data. ${ }^{19}$ Although we use a very different source of variation to identify the IES, our estimates are similar to, if on the larger end of, those obtained in micro studies from the change in consumption growth with expected changes in interest rates.

As a check of the validity of the model, we note that if our a priori beliefs imply that the subjective rate of time discount must be non-negative $(\rho \geq 0)$, our constant term in Table 3 alone puts a lower bound on $\gamma$ (c.f. Weil [1989]). In particular, suppose that ages $s$ and $t$ fall before retirement but after liquidity constraint (8) has ceased to bind and that household composition is the same at both ages. As in (2),

$$
u^{\prime}\left(c_{s}\right)=e^{(r-\rho) \cdot(t-s)} \cdot u^{\prime}\left(c_{t}\right)
$$

19 Barsky et al. [1997] use hypothetical questions to estimate an IES distribution for their sample. They find an average IES of 0.2 , with less than $20 \%$ of respondents having an IES greater than 0.3. Others who have attempted to estimate a distribution of intertemporal elasticities of substitution find evidence that the IES is increasing with wealth (e.g., Blundell et al. [1994]). 
so, if $\beta_{1}$ is our estimated constant from Table 2 , we have

$$
u^{\prime}\left(c_{s}\right)=e^{(r-\rho) \cdot(t-s)} \cdot u^{\prime}\left(c_{s} \cdot e^{\beta_{1} \cdot(t-s)}\right) \quad \Longleftrightarrow \quad \frac{r-\rho}{1-\alpha \cdot \gamma}=\beta_{1} .
$$

If $\rho \geq 0$, it follows that

$$
\frac{r}{\beta_{1}}-1 \geq-\alpha \cdot \gamma
$$

With $r=.05 \cdot(1-.1428), \beta_{1}=.0261$ from Table 3 , and $\alpha$ about .25, we then expect $\gamma \in[-2.56,1.0]$. All of the estimates of Table 5, in fact, fall comfortably within this interval, though the derivation of Table 5 in no way imposes $\rho \geq 0$.

As stated, our estimate of the intertemporal elasticity of substitution is closer to 1.0 than many in the literature. Haider and Stephens [2004] argue that earlier-thananticipated retirement on the part of some households may bias one's estimate of the average decline in consumption at retirement upward by one third. Aguiar and Hurst [2004] argue that the decline tends to be overstated because increases in home production, including shopping time, allow retirees to obtain more consumption per dollar of expenditure. On the one hand, the latter may be interpreted as somewhat similar in spirit to increased time for leisure in our model. On the other hand, a smaller empirical decline in consumption at retirement would tend to move our estimated IES even closer to the zero-change logarithmic case, where the IES is 1.0. For example, if we diminish our consumption drop by one third in the middle column at the top of Table 5 , our point estimates for gamma and alpha become -.37 and .28 , respectively; thus, our point estimate of the IES for consumption/leisure service flows rises from .63 to .73 , and our estimate of the IES for consumption alone rises from .86 to .91 .

Finally, we believe that our analysis suggests a coherent description of the practical role of liquidity constraints in the life-cycle model. Ostensibly, our results seem contradictory: 
Tables 2-3 show evidence of binding liquidity constraints only through (female) age 22, but Table 5 finds binding constraints through (female) age 30 . One pattern in all solutions of our model, however, is that constraint (8) binds, if at all, only at the beginning of life. If it binds then, the reason is that future earnings are high in youth relative to current earnings — making young households wish they could borrow against their future prosperity. In comparing our different tables, notice that the simulations of Table 5 apply to a cohort that began working in the mid 1950s. At that time, especially in the 1960s, technological progress was unusually fast, causing exceptionally rapid earnings growth. The young households of Tables 2-3, in contrast, began working in the mid 1980s and the 1990s. The time dummy variables from the male earnings regression generating Table A1 suggest an average annual rate of technological progress 1960-1970 about 3 percent per year faster than over 1980-2000. If we fix preference parameters from the middle column of Table 5 but lower household earnings growth for 1960-69 annually by 2 percent, renormalizing the level over all years to keep average lifetime earnings the same as before, we find that liquidity constraint (8) binds only through (female) age 27. If we reduce the growth rate 1960-69 by 3 percent using the same steps, the liquidity constraint never binds at all. Evidently, having the constraint bind in youth is a knife-edge phenomenon heavily dependent upon the general rate of earnings growth at the time. In the end, we believe that Tables 2-3 and 5 are fully consistent: according to the model, peak growth rates over the period 1950-2000 can cause young households to hit liquidity constraints for almost their first decade; more normal macroeconomic growth can make constraint (8) virtually irrelevant.

\section{Household Net Worth}

In each wave, the HRS collects data on household net worth. This section compares simulated net worth from our model with the survey data. As preceding sections make no reference to wealth data, the reader can view the new comparisons as providing an 
out-of-sample evaluation of our model and parameter estimates. There is a second reason the new comparisons are interesting: in contrast to many existing studies, our framework incorporates "consumption paradox" behavior, which should tend to decrease wealth accumulation prior to retirement.

Table A2, Appendix III, presents summary statistics on HRS net worth. Survey "net worth" consists of financial assets, equity in own business, real estate, and automobiles - less debt. Our model focuses on married couples, and the table shows that they have more wealth than average. Although our model implicitly includes private-pension equity in household net worth, pre-retirement HRS net worth excludes defined-benefit pension plans; thus, we further specialize our attention to married couples who are retired, and we capitalize the pension flows that they report. Row 3 of the table shows that retired couples are somewhat wealthier than couples in general; row 4 shows that private pensions augment other wealth by about one quarter. Row 5 capitalizes Social Security Benefits as well, which provides a measure of net worth that is nearly always positive.

We then regress log comprehensive net worth on year, male age, and years since (male) retirement — see Table A3, Appendix III. The regression restricts the sample to couples whose male retired at age 59-65, and for each such couple, it uses the first valid net worth observation. We use log net worth as our dependent variable (omitting the five observations for which net worth is zero or negative - see Table A2) because we believe the regressors should register percentage changes. Section 5 estimates an average retirement age of 62.5; thus, we use the regression of Table A3 to predict comprehensive net worth at male ages 62 and 63 . We make the predictions for households in which the wife (assumed two years junior to her husband) reaches 65 in the year 2000. In the case of retirement age 62 , for instance, if the standard error for our new net worth regression is $s$, the new regression coefficients are $\left(\zeta_{1}, \ldots, \zeta_{22}\right), v \equiv(1,0, .5, .5,0, \ldots, 0)$, and the matrix of regressors in Table A3 is $X$, predicted net worth is 


$$
h(\zeta, s) \equiv e^{\sum_{i=1}^{22} v_{i} \cdot \zeta_{i}+.5 \cdot s^{2}+.5 \cdot v^{\prime} \cdot\left[X^{\prime} \cdot X\right]^{-1} \cdot v \cdot s^{2}}
$$

Using maximum likelihood estimates of the covariance matrix for $(\zeta, s)$, the delta method provides a confidence interval.

Table 6. Comprehensive Household Net Worth (Including Capitalized Pension and Social Security Benefits) Predicted from Life-Cycle Model (Estimated Beta from Table 2, Column 3) and from HRS Survey Data; Year 2000 Dollars

\begin{tabular}{|c|c|c|}
\hline \multirow{2}{*}{ Specification } & \multicolumn{2}{|c|}{ Household Retirement Age: $^{a}$} \\
\cline { 2 - 3 } & 62 & 63 \\
\hline \multicolumn{3}{|c|}{ Simulation of Estimated Life-Cycle Model } \\
\hline $\begin{array}{c}\text { Model Incorporating } \\
\text { Liquidity Constraints }\end{array}$ & $\$ 686,000$ & $\$ 696,000$ \\
\hline $\begin{array}{c}\text { Model Omitting } \\
\text { Liquidity Constraints }\end{array}$ & $\$ 656,000$ & $\$ 666,000$ \\
\hline \multicolumn{2}{|c|}{ 3. HRS Data: Prediction from Regression on Data from Last Row Table A $2^{b}$} \\
\hline Mean \\
\hline $95 \%$ Confid.] & $\$ 719,000$ & $\$ 736,000$ \\
\end{tabular}

a. Male age (all households here headed by couples).

b. Omitting negative and zero values, we regress log total net worth on a constant, survey-wave and male age dummies, and years since male retirement. The sample is retired couples whose male retired age 59-65. Assuming wives are two years younger than their husbands, we predict net worth for households whose wife turned 65 in 2000.

Table 6 compares our model's simulated net worth at retirement to our corresponding estimates from the HRS. The estimates of comprehensive net worth at retirement ages 62 and 63 from the data, $\$ 719,000$ and $\$ 736,000$, respectively, closely match the corresponding values from simulations with liquidity constraint (8) - with simulated values from the 
model being about 5 percent lower than estimates from the data. Simulations based on formulations of the model without the liquidity constraint are about 10 percent lower than values from the data. Household heterogeneity, and perhaps measurement error, make the 95 percent confidence intervals for our predictions from the data extremely wide (as the coefficient of variation in Table A2 foreshadows).

In the end, our simulations quite closely agree with point estimates of comprehensive net worth from the HRS. We should note, however, that, as is the case with most surveys, the HRS does not pay special attention to the wealthiest families. The best known survey that provides a high income sample is the Survey of Consumer Finances (SCF). The SCF 2001 (e.g., Aizcorbe et al. [2003, Table 3]) seems to show noticeably more net worth than Table A2. ${ }^{20}$ We think of our model as being calibrated to the U.S. population excluding the extreme upper tail of the wealth distribution — with an analysis of the latter presumably requiring a description of intentional bequests (e.g., Modigliani [1986], Laitner [2001], and others).

\section{Conclusions}

A number of recent papers describe a substantial drop in household expenditures at retirement, a drop that some argue demonstrates the limits of a strictly rational life-cycle model. This paper reconciles the life-cycle saving model with the "retirement-consumption puzzle," and then uses the empirical change in expenditure at retirement to provide a new and, we believe, attractive source of identification for parameters of the life-cycle model.

We show that a tractable life-cycle specification with nonseparable intratemporal

20 We can compare the mean of $\$ 342,000$ and median $\$ 143,000$ from row 1 of Table A2 with SCF family net worth (see Aizcorbe) for head 55-64 (2001 dollars): 1995, mean $\$ 442,000$ and median $\$ 133,000 ; 1998$, mean $\$ 579,000$ and median $\$ 139,000 ; 2001$, mean $\$ 727,000$ and median $\$ 182,000$. 
utility, and with work options that are discrete, predicts a discontinuous change in consumption at retirement. We then show that if one is willing to thus treat the change in household consumption at retirement as a consequence of purposeful behavior, the magnitude of the change provides useful information for estimating life-cycle model parameters, especially the elasticity of intertemporal substitution. Intuitively, if a household's taste for intertemporal smoothing is sufficiently high, it will choose to decrease its consumption at retirement so that lost utility from consumption offsets gains from additional leisure. If it has a lower desire for intertemporal smoothing, on the other hand, the household might want to increase its consumption at retirement to take advantage of the complementarity of consumption and leisure. The size, and sign, of the consumption change play a crucial role in our estimation of households' IES.

Our strategy of using the consumption-retirement puzzle to estimate life-cycle parameters provides information about the robustness of existing IES estimates to variation in method of estimation and decision domain. In addition, our method has the advantage that it estimates the IES from changes associated with a highly predictable and consequential life event - retirement. The standard approach, which instruments for asset returns in period $t+1$ using economic variables known in period $t$, suffers from the problems of weak instruments. We argue that, in this sense, changes in consumption at retirement offer a more robust and credible source of variation from which to estimate this critical parameter.

We implement our identification strategy using pseudo-panel data from the U.S. Consumer Expenditure Survey 1984-2001 to estimate a consumption-Euler equation. The estimated coefficients from that equation provide composites of the structural parameters of our life-cycle model. As in previous studies, we find a substantial average drop in household expenditure at retirement. Combining the consumption coefficients with lifetime earnings profiles from Health and Retirement Study panel data, we use the model's 
prediction of the optimal retirement age, together with HRS data on retirement, to extract estimates of the structural parameters of the model.

Despite our distinctive method, we estimate intertemporal elasticity parameters that are consistent with, if on the higher end of, those found and used in the literature. We estimate, with considerable precision, an IES for services of approximately 0.67 and an IES for consumption of 0.87 .

Our estimated model performs well when we compare its predictions about retirement wealth holdings with actual wealth data from the HRS (which did not inform our estimation), and the model interestingly suggests that liquidity constraints may play a role in determining the path of consumption at young ages. Because the model is especially well suited for studying retirement behavior, our future work will use our estimates to perform policy experiments to obtain quantitative predictions of, for example, the effects of possible Social Security reforms on the labor supply of older Americans.

\section{Appendix I: Three Further Adjustments of the CEX Data}

1. We subdivide "shelter" into "services from own house" and "other." We scale the latter as we do other categories, but we drop the CEX "services from own house" and impute a substitute that allocates the annual NIPA total service flow from residential houses to the CEX in proportion to CEX reported house values.

2. CEX medical expenditures omit employer contributions to health insurance and services that Medicare covers. We annually, proportionately, and for every age adjust CEX expenditures on private health insurance to match the Department of Health and Human Services total for all premiums for private health insurance; and, we adjust outof-pocket health spending from the CEX to match annual DHHS totals. ${ }^{21}$ Turning to

21 See http://www.cms.hhs.gov/statistics/burden-of-health-care-costs/table01.asp. The annual figures cover 1987-2000. We extrapolate to 1984-86 and 2001 using the growth rate 
Medicare, funding for the benefits comes from a hospital insurance (HI) tax on wages and salaries, monthly premiums for supplementary medical insurance (SMI) from people currently eligible for benefits, and contributions from general tax revenues to SMI. The CEX registers only SMI premiums from participants; so, we allocate the yearly total of Medicare benefits (both HI and all SMI expenditure) to the CEX sample in proportion to SMI premium payments (principally for people over 65 ). ${ }^{22}$

3. The NIPA "personal business" category includes bank and brokerage fees, many of which are hidden in the form of low interest on saving accounts, etc., and hence absent from expenditures which CEX households perceive. We assume that bank and brokerage fees make their way into the life-cycle model in the form of lower-than-otherwise interest rates on saving; therefore, we normalize annual personal business expenditures measured in the CEX to match the corresponding NIPA amount less bank and brokerage fees, and omit bank and brokerage fees from our measure of consumption.

of NIPA total medical consumption.

${ }^{22}$ For HI expenditures, see Social Security Bulletin, Annual Statistical Supplement 2001, table 8.A1; for SMI receipts and receipts from participant premiums, see table 8.A2. 


\section{Appendix II: Lifetime Earnings}

Table A1. Representative Household Aftertax, Total Compensation Estimated from HRS, Imputed Household Social Security Benefit, and Imputed Household Medicare Benefit; Male Retirement Age 62; Female Retirement Age 60; Year 2000 Dollars $^{a}$

Pre-retirement

\begin{tabular}{|c|c|c|c|}
\hline $\begin{array}{l}\text { Male } \\
\text { Age }\end{array}$ & $\begin{array}{l}\text { Male/Female } \\
\text { Earnings }\end{array}$ & $\begin{array}{l}\text { Male } \\
\text { Age }\end{array}$ & $\begin{array}{l}\text { Male/Female } \\
\text { Earnings }\end{array}$ \\
\hline 24 & $13839 / 3255$ & 43 & $44412 / 9407$ \\
\hline 25 & $15294 / 3813$ & 44 & $44084 / 10168$ \\
\hline 26 & $16780 / 3714$ & 45 & $43512 / 10973$ \\
\hline 27 & $18215 / 3602$ & 46 & $42896 / 11721$ \\
\hline 28 & $20252 / 3513$ & 47 & $42289 / 12321$ \\
\hline 29 & $22384 / 3505$ & 48 & $42532 / 12667$ \\
\hline 30 & $24540 / 3673$ & 49 & $42800 / 13118$ \\
\hline 31 & $26658 / 3710$ & 50 & $43017 / 13593$ \\
\hline 32 & $28788 / 3778$ & 51 & $43192 / 13985$ \\
\hline 33 & $31224 / 4139$ & 52 & $43198 / 14329$ \\
\hline 34 & $33532 / 4482$ & 53 & $43089 / 14650$ \\
\hline 35 & $35911 / 4839$ & 54 & $42803 / 15054$ \\
\hline 36 & $38321 / 5335$ & 55 & $42572 / 15655$ \\
\hline 37 & $40805 / 5852$ & 56 & $42405 / 16263$ \\
\hline 38 & $41672 / 6325$ & 57 & $42142 / 16643$ \\
\hline 39 & $42449 / 6856$ & 58 & $42985 / 17291$ \\
\hline 40 & $43206 / 7538$ & 59 & $43667 / 17856$ \\
\hline 41 & $43857 / 7963$ & 60 & $44191 / 18266$ \\
\hline 42 & $44605 / 8502$ & 61 & $44420 / 18770$ \\
\hline \multicolumn{4}{|c|}{ Post-retirement } \\
\hline $\begin{array}{l}\text { Male } \\
\text { Age }\end{array}$ & $\begin{array}{l}\text { Household } \\
\text { SSB/Medicare Benefit }\end{array}$ & $\begin{array}{l}\text { Male } \\
\text { Age }\end{array}$ & $\begin{array}{c}\text { Household } \\
\text { SSB/Medicare Benefit }\end{array}$ \\
\hline $62-63$ & $12383 / 0$ & $67-74$ & $18575 / 10623$ \\
\hline 64 & $18575 / 0$ & $75-82$ & $12383 / 5312$ \\
\hline $65-66$ & $18575 / 5312$ & & \\
\hline
\end{tabular}

a. See text. 


\section{Appendix III: HRS Household Net Worth}

\section{Table A2. HRS Net Worth (Yr 2000 Dollars) ${ }^{a}$}

\begin{tabular}{|c|c|c|c|c|}
\hline \multirow[b]{2}{*}{ Sample } & \multirow{2}{*}{$\begin{array}{l}\text { Obser- } \\
\text { vations }{ }^{b}\end{array}$} & \multicolumn{3}{|c|}{ Weighted Sample: ${ }^{c}$} \\
\hline & & Mean & Median & $\begin{array}{l}\text { Coef. } \\
\text { Var. }\end{array}$ \\
\hline $\begin{array}{l}\text { Financial Respondent } \\
\text { Reporting Net Worth }\end{array}$ & 40023 & $\$ 342,000$ & $\$ 143,000$ & 3.02 \\
\hline $\begin{array}{l}\text { Preceding Row } \\
\text { and Married }\end{array}$ & 24626 & $\$ 426,000$ & $\$ 200,000$ & 2.58 \\
\hline $\begin{array}{l}\text { Preceding Row } \\
\text { and Retired } \\
\end{array}$ & 2821 & $\$ 485,000$ & $\$ 278,000$ & 1.87 \\
\hline $\begin{array}{l}\text { Preceding Row, Add } \\
\text { Capitalized } \\
\text { Private Pension }\end{array}$ & 2821 & $\$ 614,000$ & $\$ 411,000$ & 1.53 \\
\hline $\begin{array}{c}\text { Preceding Row, Add } \\
\text { Capitalized } \\
\text { Social Security Benefits } f\end{array}$ & 2821 & $\$ 756,000$ & $\$ 553,000$ & 1.26 \\
\hline \multicolumn{5}{|c|}{ Addendum: Signs in Preceding Row } \\
\hline & & Negative & Zero & Positive \\
\hline \multicolumn{2}{|c|}{ Observations } & 2 & 3 & 2816 \\
\hline
\end{tabular}

a. See text.

b. Waves 1992, 1994,..., 2004; hence, maximum of 6 observations per household.

c. HRS household weights.

d. Couple "retired" (i) if male never worked or self-characterized as retired, retirement age $\geq 40$, and positive Social Security benefit flow; and (ii) if spouse never worked or self-characterized as retired.

e. Pension flows capitalized at $r \cdot(1-\tau)$ where $r=.05$ if cola, otherwise $r=.075$; and $\tau=.1428$.

Mortality: male age 74; female age 80. If survey reports "pension continues at death," spouse receives full pension share after respondent's death; if "pension reduced at death," spouse receives half share after respondent's death; otherwise, we assume pension flow stops with respondent's death. We multiply all survey pension flows by $1-\tau$.

f. After age 62, spouse receives larger of one-half husband's Social Security benefit and own benefit. After husband's death, spouse receives larger of own and husband's benefit.

We multiply all Social Security benefit flows by $1-\tau / 2$. 


\begin{tabular}{|c|c|c|c|}
\hline \multicolumn{4}{|c|}{$\begin{array}{l}\text { Table A3. Regression of Log Comprehensive Net Worth } \\
\text { from Retired, HRS Couples, on a Constant, Year and } \\
\text { Male Age Dummy Variables, and Years Since Male Retirement; } \\
\text { HRS Household Weights; Male Retirement Age 59-65 }\end{array}$} \\
\hline Parameter & Coefficient & St. Err. & T Stat \\
\hline CONSTANT & 13.4315 & 0.1848 & 72.6673 \\
\hline 1992 WAVE & -0.4976 & 0.0991 & -5.0214 \\
\hline 1994 WAVE & -0.1494 & 0.1041 & -1.4344 \\
\hline 1996 WAVE & -0.3476 & 0.0865 & -4.0185 \\
\hline 1998 WAVE & -0.3079 & 0.0846 & -3.6387 \\
\hline 2002 WAVE & -0.1115 & 0.0823 & -1.3549 \\
\hline MALE AGE 59 & 0.0302 & 0.2662 & 0.1134 \\
\hline MALE AGE 60 & -0.4110 & 0.2930 & -1.4027 \\
\hline MALE AGE 61 & -0.1171 & 0.3028 & -0.3867 \\
\hline MALE AGE 63 & 0.1350 & 0.1839 & 0.7341 \\
\hline MALE AGE 64 & 0.2076 & 0.1803 & 1.1511 \\
\hline MALE AGE 65 & 0.0579 & 0.1838 & 0.3151 \\
\hline MALE AGE 66 & 0.1264 & 0.1951 & 0.6481 \\
\hline MALE AGE 67 & 0.2009 & 0.2086 & 0.9630 \\
\hline MALE AGE 68 & 0.0702 & 0.2205 & 0.3186 \\
\hline MALE AGE 69 & -0.1975 & 0.2187 & -0.9030 \\
\hline MALE AGE 70 & 0.0011 & 0.2303 & 0.0048 \\
\hline MALE AGE 71 & 0.0445 & 0.2421 & 0.1840 \\
\hline MALE AGE 72 & -0.5527 & 0.2868 & -1.9270 \\
\hline MALE AGE 73 & -0.0615 & 0.2939 & -0.2092 \\
\hline MALE AGE 74 & -0.5116 & 0.3736 & -1.3691 \\
\hline MALE RET PLUS & -0.0069 & 0.0032 & -2.1823 \\
\hline \multicolumn{4}{|c|}{ Summary Statistics } \\
\hline$R^{2}$ & \multicolumn{3}{|c|}{99.6727} \\
\hline Observations & \multicolumn{3}{|c|}{864} \\
\hline Mean Square Error & \multicolumn{3}{|c|}{.5717} \\
\hline
\end{tabular}

a. See text. 


\section{Bibliography}

[1] Aguiar, Mark; and Erik Hurst "Consumption vs. Expenditure," NBER Working Paper 10307 (2004).

[2] Altig, David; Auerbach, Alan J.; Kotlikoff, Laurence J.; Smetters, Kent A.; and Walliser, Jan, "Simulating Fundamental Tax Reform in the United States," American Economic Review, vol. 91, no. 3 (June 2001): 574-59.

[3] Aizcorbe, Ana M.; Kennickell, Arthur B.; and Moore, Kevin B., "Recent Changes in U.S. Family Finances: Evidence from the 1998 and 2001 Survey of Consumer Finances," Federal Reserve Bulletin, vol. 89 (January 2003).

[4] Attanasio, Orazio, and Guglielmo Weber, "Consumption Growth, The Interest Rate and Aggregation," Review of Economic Studies 60, (1993): 631-649.

[5] Auerbach, Alan J.; and Kotlikoff, Laurence J. Dynamic Fiscal Policy. Cambridge: Cambridge University Press, 1987.

[6] Banks, James; Blundell, Richard; and Tanner, Sarah, "Is There a Retirement-Savings Puzzle?" American Economic Review 88, no. 4 (September 1998): 769-78.

[7] Barsky, Robert; Kimball, Miles; Juster, F. Thomas; and Shapiro, Matthew, "Preference Parameters and Behavioral Heterogeneity: An Experimental Approach in the Health and Retirement Study," Quarterly Journal of Economics vol. 112, no. 2 (May 1997): 537-79.

[8] Bernheim, B. Douglas; Skinner, Jonathan; and Weinberg, Steven, "What Accounts for the Variation in Retirement Wealth Among U.S. Households," American Economic Review 91, no. 4 (September 2001): 832-57.

[9] Blundell, Richard; Browning, Martin; and Meghir, Costas, "Consumer Demand and the Life-cyle Allocation of Expenditure," Review of Economic Studies (January 1994): $57-80$.

[10] Blundell, Richard; and MaCurdy, Thomas, "Labor Supply: A Review of Alterna- 
tive Approaches," in Orley Ashenfelter and David Card (eds.), Handbook of Labor Economics: vol. 3A. Amsterdam: Elsevier, 1999.

[11] Burkhauser, Richard V.; Dwyer, Debra; Lindeboom, Maarten; Theeuwes, Jules; and Woittiez, Isolde, "Health, Work, and Economic Well-Being of Older Workers, Aged Fifty-One to Sixty-one: A Cross-National Comparison Using the U.S. HRS and the Netherlands CERRA Data Sets," in James Smith and Robert Willis (eds.), Wealth, Work, and Health: Innovations in Measurement in the Social Sciences. Ann Arbor: The University of Michigan Press, 1999.

[12] Campbell, John; and Mankiw, N. Gregory, "Consumption, Income and Interest Rates: Reinterpreting the Time Series Evidence," NBER Macroeconomics Annual MIT Press (1989): 185-216.

[13] Cooley, Thomas; and Prescott, Edward "Economic Grwoth and Business Cycles" in Thomas Cooley (ed.), Frontiers of Business Cycle Research. Princeton, N.J., Princeton University Press (1995): 1-38.

[14] Diamond, P.A., "National Debt in a Neoclassical Growth Model," American Economic Review, vol. 55, no. 5 (December 1965): 1126-1150.

[15] Gokhale, Jagadeesh; Kotlikoff, Laurence J.; Sefton, James; and Weale, Martin, "Simulating the Transmission of Wealth Inequality via Bequests," Journal of Public Economics vol. 79, no. 1 (January 2001): 93-128.

[16] Gustman, Alan L.; and Steinmeier, Thomas, L., "A Structural Retirement Model," Econometrica vol. 54, no. 3 (May 1986): 555-84.

[17] Haider, Steven; and Stephens, Melvin, Jr., "Is There a Retirement-Consumption Puzzle? Evidence Using Subjective Retirement Expectations," NBER Working Paper 10257, (2004).

[18] Hall, Robert E., "Intertemporal Substitution in Consumption," Journal of Political Economy 96, no. 2 (1988): 339-357. 
[19] Hubbard, R. Glen; and Judd, Kenneth, "Liquidity Constraints, Fiscal Policy and Consumption," Brookings Papers on Economic Activity 1 (1986): 1-50.

[20] Hubbard, R. Glen; Skinner, Jonathan; and Zeldes, Stephen P., "Precautionary Saving and Social Insurance," Journal of Political Economy 103, no. 2 (April 1995): 360-99.

[21] Hurd, Michael, "The Effect of Labor Market Rigidities on the Labor Force Behavior of Older Workers," in (David Wise ed.), Advances in the Economics of Aging. Chicago: The University of Chicago Press, 1996.

[22] Hurd, Michael; and Rohwedder, Susann, "The Retirement-Consumption Puzzle: Anticipated and Actual Declines in Spending at Retirement," NBER working paper 9586 (2003), http://www.nber.org/papers/w9586.

[23] Jones, Larry E.; Manuelli, Rodolfo; Siu, Henry; and Stachetti, Ennio "Fluctuations in Convex Models of Endogenous Growth I: Growth Effects," mimeo, University of Minnesota (November 2003).

[24] Keane, Michael; and Wolpin, Kenneth, "The Effect of Parental Transfers and Borrowing Constraints on Educational Attainment," International Economic Review 42, No. 4 (November 2001): 1051-1103.

[25] King, Robert; Plosser, Charles; and Rebelo, Sergio, "Production, Growth and Business Cycles: I. The Basic Neoclassical Model," Journal of Monetary Economics vol. 21, no. 2 (1988): 195-232.

[26] Laitner, John, "Secular Changes in Wealth Inequality and Inheritance," The Economic Journal, vol. 111, no. 474 (October 2001): 691-721.

[27] Lucas, Robert E., Jr., "Supply Side Economics: An Analytical Review," Oxford Economic Papers vol. 42 (April 1990): 293-316.

[28] Lucas, Robert E., Jr., "Macroeconomic Priorities," The American Economic Review vol. 93. no. 1 (March 2003): 1-14.

[29] Mariger, Randall P. Consumption Behavior and the Effects of Government Fiscal 
Policy. Cambridge: Harvard University Press, 1986.

[30] Meghir, Costas; and Weber, Guglielmo, "Intertemporal non-separability or Borrowing Restrictions? A Disaggregate Analysis Using a US Consumption Panel," Econometrica vol. 64, no. 5 (September 1996): 1151-1181.

[31] Modigliani, Franco, "Life Cycle, Individiual Thrift, and the Wealth of Nations," American Economic Review 76, no. 3 (June 1986): 297-313.

[32] Paterson, Kerry D.; and Pesaran, Bahram, "The Intertemporal Elasticity of Substitution in Consumption in the U.S. and in the U.K.," Review of Economics and Statistics 74, no. 4 (May 1992): 573-84.

[33] Pencavel, John, "Labor Supply of Men: A Survey," in Orley Ashenfelter and David Card (eds.), Handbook of Labor Economics: vol. 1. Amsterdam: Elsevier, 1986.

[34] Rust, John; and, Phelan, Christopher., "How Social Security and Medicare Affect Retirement Behavior in a World of Incomplete Markets," Econometrica 65, no. 4 (July 1997): 781-831.

[35] Stock, James H.; and, Wise, David A., "Pensions, The Option Value of Work, and Retirement," Econometrica 58, no. 2 (September 1990): 1151-1180.

[36] Tobin, J., "Life Cycle Saving and Balanced Growth," in W. Fellner (ed.), Ten Economic Studies in the Tradition of Irving Fisher. New York: Wiley, 1967.

[37] Weil, Philippe, "The Equity Premium Puzzle and the Risk-Free Rate Puzzle," Journal of Monetary Economics, vol. 24, no. 3 (November 1989): 401-21.

[38] Yogo, Motohiro, "Estimating the Elasticity of Intertemporal Substitution When Instruments Are Weak," Review of Economics and Statistics, vol. 86, no. 3, (August 2004): 797-810.

[39] Zeldes, S., "Consumption and Liquidity Constraints: An Empirical Investigation," Journal of Political Economy 97, no. 4 (April 1989): 305-46. 